\title{
Low salinity intrusions in the western English Channel
}

\author{
B.A. Kelly-Gerreyn ${ }^{a} \star$, D.J. Hydes ${ }^{a}$, A.M. Jégou ${ }^{b}$, P. Lazure ${ }^{b}$, L.J. Fernand ${ }^{c}$, I. Puillat ${ }^{d}$, \\ C. García Soto
}

\begin{abstract}
${ }^{a}$ National Oceanography Centre, Southampton, University of Southampton, Waterfront Campus, European Way, Southampton, SO14 3ZH, UK

'IFREMER, Direction de l'Environnement Littoral, Service Applications Opérationnelles, B.P 70, 29280 Plouzané, France

${ }^{c}$ Centre for Environment, Fisheries and Aquaculture Sciences, Pakefield Road, Lowestoft, NR33 OHT, UK

dLOCEAN, Laboratoire d'Océanographie et de Climatologie: Expérimentation et Analyse Numérique, Université Pierre et Marie Curie , 4 place Jussieu , 75252 Paris cedex 05, France

e Instituto Español de Oceanografía, Promontorio San Martín s/n 39004, Santander, Spain
\end{abstract}

*: Corresponding author : B.A. Kelly-Gerreyn, tel: +44 23 80596334; fax: +44 23 80596247. E-mail address : $\underline{\text { bag@noc.soton.ac.uk }}$

\begin{abstract}
:
Low salinity $(<35)$ surface waters (LSSW) at the southern entrance to the western English Channel $\left(48.5^{\circ} \mathrm{N}, 5.1^{\circ} \mathrm{W}\right.$, near Ushant) were observed in late winter (March-April) in three successive years (2002-04) during near continuous ship of opportunity operations. The source of the LSSW is the northward spreading plumes from the Loire $\left(47.5^{\circ} \mathrm{N}, 2.5^{\circ} \mathrm{W}\right)$ and Gironde $\left(45.6^{\circ} \mathrm{N}, 1.2^{\circ} \mathrm{W}\right)$ along the French Atlantic coast. Fastest plume travel times were associated with northeasterly winds, consistent with Ekman theory. Differences between years in the mean winter (January-March) combined river discharges (D) was consistent with the minimum salinities (Smin) of the LSSW (2004: $D=4211 \mathrm{~m} 3$ $\mathrm{s}-1$, Smin=33.68; 2003: $D=3630 \mathrm{~m} 3 \mathrm{~s}-1$, Smin=33.90; 2002: $\mathrm{D}=1579 \mathrm{~m} 3 \mathrm{~s}-1$, Smin=34.53). Winter mean (1905-74) salinity is otherwise 35.33 near Ushant.

The LSSW intruded into the western English Channel in each year, suggesting a common phenomenon. The low salinity intrusion was freshest (mean=35.11 \pm 0.21 ) and most penetrative (reaching $50.7^{\circ} \mathrm{N}, 1.0^{\circ} \mathrm{W}$ by the end of the year) in 2003 on account of (1) entering on a spring tide giving greater tidal excursion into the western English Channel and (2) intrusion favourable winds (southwesterly/southeasterly) acting on the longer term residual flow. Less penetration occurred in 2004 when the arrival of the LSSW coincided with a neap tide followed by intrusion-resistant northwesterly winds, resulting in a less saline (mean $=35.20 \pm 0.23$ ) intrusion. In 2004, transport tended to be offshore to at least $100 \mathrm{~km}$ from the French Atlantic coast $\left(47^{\circ} \mathrm{N}, 4.8^{\circ} \mathrm{W}-48^{\circ} \mathrm{N}, 4.7^{\circ} \mathrm{W}\right)$. In 2002 , the lower volume of plume water relative to the other years produced a more saline intrusion (mean $=35.25 \pm 0.12$ ). Prevailing westerly winds may have pushed this intrusion northwards beyond the route of the ferry, making it difficult to assess the true extent of the intrusion in 2002. A link of the LSSW to phases of the winter North Atlantic Oscillation index from a literature search of the last 84 years was inconclusive.
\end{abstract}

Keywords: Low salinity; Ferrybox; River plume; English Channel; Bay of Biscay 


\section{Introduction}

2 The English Channel (Fig. 1) is a well studied region with many interesting

3 oceanographic features (see Pingree, 1980 and Southward et al, 2005 for extensive

4 reviews). The earliest studies date back to the $18^{\text {th }}$ and $19^{\text {th }}$ century (Rennell, 1793,

5 Dickson, 1891). Given this long oceanographic history, a coherent understanding of

6 particular features in the English Channel and its western approaches has yet to be

7 fully established. One such feature is the low salinity $(<35)$ surface waters (LSSW)

8 which appear at the southern entrance to the western English Channel (near Ushant,

9 Fig. 1) at the end of winter in some years (Table 1). The late winter mean for this area

10 is 35.33 (Table 1). Poole and Atkins (1929) concluded that this low salinity water was

11 an "abnormal condition" and they were the first to make a link to French Atlantic

12 river runoff by relating years of higher than average (>50\%) rainfall in the River Loire

13 basin to the same years in which the LSSW occurred. This link is corroborated by

14 field and modelling studies (Lazure and Jégou, 1998; Puillat et al., 2004) showing

15 plumes of the Loire and Gironde estuaries (Fig. 1) spreading northwards along the

16 French Atlantic coast in winter, reaching as far north as western Brittany (Fig. 1)

17 given favourable wind conditions (Lazure and Jégou, 1998, Puillat et al., 2004).

18 The fate of the LSSW is less certain. Cooper (1960) suggested that the influence of

19 these waters extended into the eastern English Channel, as well as to the western coast

20 of southern England. Contrastingly, Taylor et al., (1981) concluded from a modelling

21 study that variations in salinity at the entrance to the western English Channel have

22 little effect on salinity fluctuations in the eastern English Channel. Table 1 shows that

23 the lowest recorded salinity (33.90) at the southern entrance to the English Channel

24 occurred in February 1936. For most of 1936, the whole of the English Channel had 
1 low surface salinity, which Pingree (1980) stated could not be fully explained by

2 higher than average rainfall alone.

3 In this study, the evolution of the LSSW was monitored in unprecedented detail with

4 data from a ship of opportunity operating year-round between Portsmouth (UK) and

5 Bilbao (Spain) since April 2002. These data are combined with contemporaneous

6 measurements of wind, tides and river flows from the French Atlantic coast. This

7 enables the gap between previous field studies (i.e. English Channel based studies and

8 French Atlantic shelf studies) to the bridged and the link between meteorology and

9 hydrodynamics and the fate of the low salinity waters to be investigated appropriately

10 for the first time. The hypothesis is that river runoff from the French Atlantic coast is

11 directly linked to the low salinity observed periodically in the English Channel..

\section{Data and methods}

14 The surface water data presented here were collected between April 2002 and 15 August 2004 on a ship of opportunity (P \& O European Ferries Ltd ship "Pride of 16 Bilbao") operating between Portsmouth (UK, $50.8^{\circ} \mathrm{N}, 1.1^{\circ} \mathrm{W}$ ) and Bilbao (Spain, $43.4^{\circ} \mathrm{N}, 3.0^{\circ} \mathrm{W}$ ) (Fig. 1). The ship makes two crossings weekly between these ports.

18 The distance is approximately $1000 \mathrm{~km}$ and the journey time is about 35 hours each 19 way. This gives a repeat sampling rate of between 4 hours and 4 days, depending on 20 location. The service operates year round except for January when the ship is in dry 21 dock for its annual refit.

22 The ferry route (Fig. 1) crosses many water types: eutrophic harbours, coastal well 23 mixed and stratified waters, a shelf break and deep (4000 m) waters (the central Bay 24 of Biscay). This work is part of the EU-Framework-5 project "FerryBox" 25 (http://www.ferrybox.org/). 


\subsection{FerryBox data}

3 Measurements are made of conductivity (accuracy and precision: $0.005 \pm 0.001$

4 mmho $\left.\mathrm{cm}^{-1}\right)$, temperature $\left(0.003 \pm 0.0005^{\circ} \mathrm{C}\right)$, pressure and chlorophyll-flourescence

5 (0.01 $\left.\pm 0.01 \mathrm{mg} \mathrm{Chl} \mathrm{m}{ }^{-3}\right)$ using MiniPack sensors (Chelsea Technologies Group

6 MiniPack claim these sensor performances) installed in the engine room. The sampled

7 water is taken from the ship's cooling water supply at a depth of 5 metres. The flow

8 rate in the system is $15-20$ litres per minute giving a residence time of 3-4 seconds

9 before the water reaches the sensors. The sensors are cleaned on a weekly basis when 10 the ship is in port (Portsmouth).

11 Data were logged at a rate of $1 \mathrm{~Hz}$ on a NOC (National Oceanography Centre, 12 Southampton) designed UNIX based logging and control system (DAPS). Download 13 of the data occurs once a week. Public domain Matlab routines 14 (http://marine.csiro.au/ morgan/seawater) provide the calculations for salinity based 15 on UNESCO (1983) algorithms.

\subsection{Water samples and calibration of sensors}

18 Manned crossings occurred approximately monthly during 2003 and 2004. One such

19 crossing was made in May 2002. Water samples were collected from a spur tap

20 located before the sensors. Sample collection was maintained round the clock in both

21 directions by three people. Salinity samples were collected in $250 \mathrm{ml}$ containers at

22 intervals of 2 hours during the crossings (36 samples per crossing). On return to the

23 laboratory the salinity of the samples was measured in a temperature controlled

24 laboratory on a Guildline ${ }^{\mathrm{TM}}$ salinometer standardised with OSI Standard Seawater.

25 Calibration of the conductivity measurements had a precision (standard error) that 
1 varied between 0.034 and 0.010 . This information was then used to adjust the

2 MiniPack output for changes through time. The calibration factor varied between

3 1.063 and 1.067 in 2003 and drifted from 1.074 in March to 1.065 in December in

42004 (all $\left.\mathrm{r}^{2}>0.99, \mathrm{p}<0.0001\right)$. Only one calibration factor was applied in 2002 (1.044).

5 Comparison between the years in the region of most stable salinity (45.0-45.5 ${ }^{\circ}$, Fig.

6 1) yielded the same mean salinity (35.60 \pm 0.05 (standard deviation)). The

7 temperature sensor is calibrated annually by the manufacturer.

$9 \quad 2.3$ Wind, tide and river flow data

10 Wind speed and direction data on three hourly intervals for January 2002 to July

112004 were provided by the UK Meteorological Office for two stations (Fig. 1) along

12 the French Atlantic coast: Ushant $\left(48.5^{\circ} \mathrm{N}, 5.1^{\circ} \mathrm{W}\right)$ and Chassiron $\left(46.03^{\circ} \mathrm{N}, 1.25^{\circ} \mathrm{W}\right)$.

13 The stations were chosen as they are representative of wind influences between the

14 Gironde outflow area and the southern entrance to the western English Channel

15 (Lazure and Jégou, 1998). Note prevailing winds were similar at the two stations.

16 In the absence of real tidal gauge data from Ushant, data from Jersey (St. Helier, $1749.18^{\circ} \mathrm{N}, 2.12^{\circ} \mathrm{W}$, Fig. 1) have been used. These data (2002-2004), provided by the

18 National Tidal and Sea Level Facility (UK), have been adjusted by subtracting $\sim 2$

19 hours from the time stamp to approximate the timing in the tidal cycle at Ushant

20 (Pingree, 1980).

21 River flow data (daily mean) for the Loire and Gironde covering the period from

22 January 2002 to July 2004 were provided by the French National Database for

23 Hydrometry and Hydrology (HYDRO). The Loire and the Gironde are the two main

24 estuaries on France's Atlantic coast (Fig. 1) but note that other river discharges along 
1 the south Britanny coast (e.g.la Vilaine) add winter runoff that can amount to 20\% of

2 the Loire discharge.

4 3. Results

\section{$5 \quad 3.1$ Salinity from the FerryBox}

6 Salinity data (5 minute averages of the $1 \mathrm{~Hz}$ data) along the ferry route for all 7 available times between $16^{\text {th }}$ April 2002 (day 106, note day $1=1^{\text {st }}$ January of each 8 year) and $12^{\text {th }}$ August 2004 (day 224, day numbers used from here on) are presented

9 in Figures 2. Note that interannual comparisons are made for the period starting with 10 the arrival of a low salinity signal (section 3.2.1) at the southern entrance to the 11 western English Channel (Ushant, Fig. 1) to day 200 of each year. This day was the 12 last measurement taken prior to the Ferrybox system failing in 2002. The timing of the 13 arrival of the low surface salinity signal was different among the three years..

\subsubsection{Salinity}

16 A visual inspection of Figures 2a-c reveal similarities in the overall distribution of salinity between the ports in each year. Salinity is generally lower in the northern, shelf sections (western English Channel, $>48^{\circ} \mathrm{N}$ ) compared to more southern, oceanic regions such as the Bay of Biscay $\left(<46^{\circ} \mathrm{N}\right)$. The north-south boundary that divides the salinity into lower and higher values is broad, lying between $47^{\circ} \mathrm{N}$ and $49^{\circ} \mathrm{N}$

21 depending on the time of year - the boundary was more southerly early in the year compared to later in the year in both 2003 (Fig. 2b) and 2004 (Fig. 2c). In contrast, the

23 boundary moved southwards in 2002 until day 200, after which the FerryBox system

24 failed (Fig. 2a). A quantitative assessment of these differences is shown in Table 2

25 (note that comparisons between years are those periods for which data were available 
1 in each of the three years, see section 3.1). The difference in salinity between the

2 years is statistically significant $(\mathrm{p}<0.0001)$ as is the spatial difference within each

3 year $(\mathrm{p}<0.0001)$. Mean salinity increased between the western English Channel and

4 the Bay of Biscay in both 2002 and 2003 (Table 2). Mean salinity was lowest (34.95,

5 Table 2) on the continental shelf (2004) and highest (35.46) in the Bay of Biscay

6 (2003). With the exception of the latter, highest average salinity values were recorded

7 in 2002 along all regions of the ferry track. The lowest salinity values were measured

8 in 2004 along all parts of the ferry track, except in the western English Channel where

9 the lowest salinities $($ mean $=35.11$ ) were recorded in 2003 (Table 2). Variability in

10 salinities (see standard deviations in Table 2) decreased between the western English

11 Channel and the Bay of Biscay in both 2002 and 2003. The highest variability in

12 salinity values among the years occurred in 2004. In this year, the standard deviation

13 was maximum (0.26) on the continental shelf and minimum (0.18) on the shelf break.

14 Standard deviation in the Bay of Biscay in 2004 was 4 to 5 times higher than in 2002 15 and 2003.

\subsubsection{Low salinity surface water (LSSW)}

18 Low salinity surface water (LSSW, defined as waters with salinities <35) was 19 observed between March and mid-April in the vicinity of Ushant ( 48.5 $\mathrm{N}$, Fig. 2a-c) 20 in all three years. The minimum salinity at this location in each year was 34.51 in 212002 (day $109,48.43^{\circ} \mathrm{N}, 5.31^{\circ} \mathrm{W}$ ), 33.90 in 2003 (day 91, $48.17^{\circ} \mathrm{N}, 5.33^{\circ} \mathrm{W}$ ) and 2233.68 in 2004 (day $61,48.36^{\circ} \mathrm{N}, 5.35^{\circ} \mathrm{W}$ ). All of these salinity values are among the 23 lowest reported for this region (cf. Table 1). Note that this LSSW was apparent at the 24 start of Ferrybox operations in 2002 (day 106, Fig. 2a), appeared on day 77 in 2003 25 (Fig. 2b) and on day 60 in 2004 (Fig. 2c). This surface water feature moved 
1 northeastwards into the western English Channel in all years ( $>48.5^{\circ} \mathrm{N}$, Fig. 2a-c).

2 Low salinity waters ( $<35$, green colour, Fig. $2 b)$ entered the western English Channel

3 in 2003, while higher salinity water ( $\geq 35$, yellow colour) intruded in 2002 (Fig. 2a)

4 and 2004 (Fig. 2c). This surface water feature moved furthest into the western English

5 Channel in 2003 (observable after day 330 at $50.7^{\circ} \mathrm{N}, 1^{\circ} \mathrm{W}$, Fig. 2b).

6 In 2004, a persistent patch of low salinity water $(<34.6)$ was observed more than 100

$7 \mathrm{~km}$ from the French Atlantic coast (ferry route between $47^{\circ} \mathrm{N}$ and $48^{\circ} \mathrm{N}$, Fig. 1 ) during

8 days 90 and 180 (Fig. 2c). In 2003, patches of less saline water (35-35.4) occurred

9 along the ferry track towards the end of May (day $\sim 140$ ) at approximately $47^{\circ} \mathrm{N}$ (Fig.

10 2b). These patches spread in a south eastwards direction and were detectable until the

11 middle of July (day 195).

12

\section{Discussion}

14 To understand the observed salinity distributions, river discharges, wind conditions 15 and tidal states between the mouth of the Gironde and the western English Channel 16 need to be considered. Freshwater discharges reduce surface salinity locally and are transported by wind and density driven currents along the French Atlantic coast

18 (Puillat et al, 2004). Strong tidal currents (up to $260 \mathrm{~cm} \mathrm{~s}^{-1}$, Pingree, 1980) dominate

19 the transport regime further north (off western Brittany, Fig. 1), and are responsible 20 for the formation of a persistent front - the Ushant front (Pingree et al., 1982, Mariette 21 and Le Cann, 1985) which extends into the western English Channel. The main direct 22 river discharge into the English Channel comes from the river Seine (Fig. 1). However, 23 a number of modelling (Lacroix et al., 2004, Cugier et al., 2005) and field (Brylinski 24 et al., 1996) studies have shown that the Seine plume travels eastwards as a coastal 
1 current into the southern North Sea. Hence, the influence of the river Seine in the area

2 of the ferry route (Fig. 1) is assumed to be negligible.

3 Field and modelling studies suggest that the presence of lower salinity waters in late

4 winter on the south coast of Brittany is the result of northward flowing plumes from

5 the Loire and Gironde estuaries (Lazure and Jégou, 1998; Puillat et al., 2004; Waeles

6 et al., 2004). In winter (maximum runoff), these plumes are mainly driven by density

7 currents that usually spread northwards, along shore due to the earth's rotation. The

8 tides are sufficiently weak on the west coast of France prior to reaching Ushant that

9 they have little effect on the water mass circulation (Pingree and Le Cann, 1990). The

10 northward flow of the plumes is similar (speed and direction) among years despite

11 interannual differences in river discharges, according to model simulations performed

12 of a 7-year period (Lazure and Jégou, 1998). However, the distance travelled to the

13 north by the plumes is different between years in the modelling study, a finding that

14 has been subsequently supported by analysis of 10 years of hydrographic data in the

15 Bay of Biscay (Puillat et al., 2004). The frequency with which these low salinity

16 waters reach as far north as Ushant seems low (Table 1). This frequency is likely to be

17 due to interannual differences in prevailing winds, given the weak link to river

18 discharge magnitudes suggested by Lazure and Jégou (1998). The analysis of Puillat

19 et al., (2004) and the modelling study of Lazure and Jégou (1998) show that

20 downwelling-favourable winds (southeasterly) along the coast enhance the northward

21 density-driven spreading of plumes while northwesterly winds which induce coastal

22 upwelling through Ekman transport can stop and even reverse this flow, dispersing

23 low-salinity waters offshore, particularly during periods of low river discharge. The

24 salinity data (Fig. 2a-c) shows that LSSW appears at the southern entrance to the

25 western English Channel in all three years of FerryBox operations. Therefore, on the 
1 basis of the preceding discussion, it is expected that in 2002-2004, prevailing winds

2 were favourable in promoting the northward transport of the river plumes in the

3 period between peak winter river flows and the arrival of the plume waters near

4 Ushant. To investigate this expectation, the relative roles of the river discharges and

5 winds along the French Atlantic coast are considered in the following section.

6

4.1 The source of the low salinity signal near Ushant $\left(48.1^{\circ} \mathrm{N}-48.5^{\circ} \mathrm{N}, 4.4^{\circ} \mathrm{W}\right.$ 4.6 $\left.6^{\circ} \mathrm{W}\right)$

\subsubsection{River discharge}

11 Freshwater discharges from the Loire and Gironde estuaries, are usually synchronous 12 (Puillat et al., 2004). High runoff occurs in winter and sometimes in early spring, 13 often with the maximum peak in February or March and the lowest level in August 14 and September. Inter-annual variations of freshwater discharges are well-known 15 (Puillat et al., 2004).

16 Discharges from the Loire and Gironde between January and July in 2002, 2003 and 172004 are shown in Figure 3a-c. Combined outflow (Loire + Gironde) for the winter period (January-March) was lower in 2002 (Fig. 3a, mean $=1579 \mathrm{~m}^{3} \mathrm{~s}^{-1}$ ) than in 2003

19 (Fig. 3b, mean $=3630 \mathrm{~m}^{3} \mathrm{~s}^{-1}$ ) and highest in 2004 (Fig. 3c, mean $=4211 \mathrm{~m}^{3} \mathrm{~s}^{-1}$ ). These 20 interannual differences in river flows are consistent with the differences in the 21 minimum recorded salinities near Ushant among these years (Table 3) ie lowest 22 minimum salinity occurred in 2004 when a higher volume of water was discharged 23 from the rivers and highest minimum salinity occurred in 2002 when a lower volume 24 of water was discharged. 
1 Time series of salinity measurements in the vicinity of Ushant between 2002 and 2004

2 are shown in Figure 3d-f. Note the large scatter of data during the period of the LSSW

3 in each year is due to the highly energetic tidal regime near Ushant (see section 4.2)

4 Comparison of the times of the peak river discharge and the arrival of LSSW near

5 Ushant (Fig. 3d-f) yield estimates of plume travel times and mean current speeds

6 (Table 3). Plume travel times were shortest in 2004 (41 days), longer in 2002 (47 days)

7 and longest in 2003 (50-84 days). Calculated mean current speeds were therefore

8 between 3.6 and $7.3 \mathrm{~cm} \mathrm{~s}^{-1}$ in late winter among the years (Table 3), which are similar

9 to previous estimates from observations and models in this region $\left(<10 \mathrm{~cm} \mathrm{~s}^{-1}\right.$, Le

10 Cann, 1990; Lazure and Jégou, 1998).

11 If density differences alone drive the flow of the plumes, it would be expected that 12 the higher the river discharge, the shorter the time for the plumes to travel northwards.

13 This expectation is partially consistent in that the highest river discharge (2004) had 14 the fastest plume travel time (Table 3). However, plume travel times were longer in 152003 compared to 2002, even though river discharge was more than double in 2003 16 (Table 3). Analysis of wind data (speed and direction) from the French Atlantic coast may help to explain the difference in plume travel times among the years.

\subsubsection{Wind Forcing}

20 Wind data from Chassiron (Fig. 1) show that there were marked differences in the 21 wind patterns between 2002 and 2004 (Fig. 4a-c) in the period between maximum 22 river outflow and the arrival of LSSW near Ushant. In 2003, the 34 day period 23 between the first and second peak flows in the Loire outflow (days 7 to 41, Fig. 3b) 24 was characterised by predominantly northwesterly winds (Fig. 4b) with a mean speed 25 of $6.9 \mathrm{~m} \mathrm{~s}^{-1}$ (Table 3). The following 50 day period leading up to the arrival of the 
1 LSSW near Ushant in 2003 (day 91), was defined by mixed directional winds

2 (northeasterly, southeasterly, southwesterly, easterly) (Fig. 4b), with a lower mean

3 wind speed of $4.8 \mathrm{~m} \mathrm{~s}^{-1}$ (Table 3). Contrastingly, northeasterly winds prevailed in

42002 (Fig. 4a, mean $=5.5 \mathrm{~m} \mathrm{~s}^{-1}$ ) and 2004 (Fig. 4c, $6.1 \mathrm{~m} \mathrm{~s}^{-1}$ ) between the peak river

5 outflow and the arrival of LSSW near Ushant (Table 3) after an initial period ( 20

6 days) of variable winds. Thus, fastest plume travel times occurred in years in which

7 there were periods of sustained northeasterly winds (2002 and 2004, Table 3) and

8 stronger winds yielded stronger mean currents (2004, Table 3). Ekman theory predicts

9 that northeasterly winds enhance the northward plume currents along the French

10 Atlantic coast, helping to spread the river plumes towards Ushant. In contrast,

11 northwesterly winds (as prevailed in the period between the first and second peak in

12 the Loire outflow in 2003, Fig. 4b) provide most resistance to northwards flowing

13 river plumes by spreading them offshore from the south coast of Brittany (Lazure and

14 Jégou,1998, Puillat et al, 2004). This explains the slowest plume travel time of 84

15 days in 2003 (Table 3). However, the plume travel time after the second peak in the

16 Loire discharge (day 41) in 2003 was only slightly longer (by 3-9 days) than the other

17 years (Table 3). This is because the majority of the winds (southeasterly,

18 southwesterly, northeasterly, Fig. 4b) in this period favoured the northward transport

19 of the plumes. Southeasterly winds are downwelling favourable which encourages

20 northward plume transport but reduces stratification (Puillat et al, 2004).

21 Southwesterly winds, though not favourable to northwards transport in the surface

22 layer, produce a mean (surface to bottom) barotropic flow which is northwards due to

23 an external pressure gradient resulting from a mean sealevel rise at the coast (Pingree

24 and Le Cann, 1990). Consequently, the expectation that winds favourable to

25 northwards plume transport prevailed in the period between peak river discharges and 
1 the arrival of LSSW near Ushant in all three years of FerryBox observations has been

2 fulfilled (section 4).

3 It is concluded that although freshwater induced density currents flow towards

4 Ushant along the French Atlantic coast, due to the Earth's rotation, the interannual

5 variability in the prevailing wind conditions determines the interannual variability in

6 the plume dynamics (northwards extent and journey times). The magnitude of the 7 river discharge determines the minimum salinity value of the waters in late winter at 8 the southern entrance of the western English Channel (Table 3).

\subsubsection{The frequency of the LSSW near Ushant}

11 The LSSW at the end of winter near Ushant (Fig. 2a-c) were observed in all three 12 years even though different river flow and wind conditions prevailed in each of the 13 years (Fig 4a-c, Fig 5a-c,). This would suggest that 1 ) the low salinity feature is not an 14 “abnormal condition” as concluded by Poole and Atkins (1929), and that 2) it is not 15 only associated with high river flows (thus giving only weak support to the hypothesis 16 in section 1). The first suggestion is strengthened by the fact that salinities <35 occurred only 20 times near Ushant in late winter-early spring between 1903 and 1974 (Table 1). There is no evidence of a change in frequency in the occurrence of the LSSW since the mid-1970s, due to a lack of frequent monitoring. The measurement of

21 frequency, year-round monitoring capability of the FerryBox system, which contrasts 22 with the lower resolution data of all previous sampling studies in this region. 23 Consequently, the LSSW may be more common than indicated by the literature search

24 (Table 1). The second suggestion supports the model results of Lazure and Jégou 25 (1998) that northward currents from the Bay of Biscay towards the English Channel 
1 occur irrespective of the magnitude of the river discharges as a result of the Earth's

2 rotation acting on the density driven currents in the presence of weak tidal currents

3 (prior to reaching Ushant, see section 4.2). However, this does not discount the

4 possibility of a threshold river discharge below which plume waters become too

5 diluted to distinguish from surrounding waters before reaching Ushant.

6

$7 \quad 4.2$ The transport of the low salinity waters beyond Ushant

8 Ushant is a region of strong tidal currents of up to $260 \mathrm{~cm} \mathrm{~s}^{-1}$ with a tidal range $>8 \mathrm{~m}$

9 (Pingree, 1980). Hence, mixing of water masses over time scales of hours and days

10 will be dominated by tides off western Brittany. This explains the large scatter in the

11 salinity signal near Ushant (Fig. 3d-f). Over longer time scales (order one week to one

12 year) there is a longer term residual component to the flow from west to east in the

13 English Channel (Pingree and Maddock, 1977). These long term currents are up to

14 two orders of magnitude lower than the tidal currents and are dependent on weather

15 conditions (Salomon \& Breton, 1993). The degree to which waters (particularly the

16 LSSW) near Ushant become part of the residual flow through the English Channel

17 depends on when the waters arrive relative to the tidal cycle. If the arrival of the

18 LSSW coincides with a neap tide there will be less of a tidal excursion (4.8-6.5 km, R.

19 Pingree, pers. comm.) into the western English Channel than during a spring tide

20 (11.2-15.2 km, R. Pingree, pers. comm.). The expectation is therefore that the LSSW

21 arrived near Ushant on a stronger (spring) tide in 2003 and on a weaker (neap) tide in

22 2004, giving rise to the more extensive and lower salinity intrusion in 2003 (Fig. 2b).

23 The data representing the tidal cycle at Ushant supports this expectation (Fig. 5a, b).

24 These tidal data also show that even though the LSSW arrived at the end of a spring

25 tide in 2002 (Fig. 5c) the lower volume of "fresh" water (2002 had lowest river 
1 discharges, Table 3) was readily mixed resulting in the weaker and more saline

2 surface water intrusion in 2002 (Fig. 2a). Note that the tidal data used here is from

3 Jersey, where both the tidal amplitude and the timing of the tidal cycle is different

4 from Ushant (section 2.3). However, the difference in timing between Jersey and

5 Ushant is small ( 2 hours 45 minutes, R. Pingree, pers. comm.) compared to the daily

6 time scales considered here with respect to the arrival of the LSSW at the southern

7 entrance to the western English Channel. Consequently, the important point about the

8 arrival of the LSSW and the spring-neap tidal cycle is unaffected by the use of the

9 Jersey data.

10 A modelling study of long-term currents in the English Channel (Salomon and 11 Breton 1993) shows that northerly (northeast to northwest) winds reverse the long12 term flow from eastwards to westwards through the English Channel, in contrast to all 13 other wind directions. Southerly component winds least resist and most constrain 14 (horizontally/latitudinally) the eastwards flow, while westerly winds produce a 15 northwards and then an eastwards trajectory from Ushant (Salomon and Breton 1993). 16 These model predictions help to explain differences in the fate of the long-term 17 trajectories of the LSSW from Ushant. Wind data from Ushant show contrasting 18 prevailing winds among the three years (Fig. 6). In 2002, the winds were 19 predominantly westerly in the two months following the arrival of the LSSW near 20 Ushant (Fig. 6a). This would mean that the LSSW travelled along a northwards and 21 then eastwards trajectory from Ushant into the western English Channel according to 22 the model simulations of Salomon and Breton (1993). Consequently, less of the 23 LSSW entering the western English Channel would be captured by the ferry route 24 (Fig. 1) in 2002 compared to 2003 and 2004 (Fig. 2a-c). In 2003, the prevailing winds 25 (southeasterly/southwesterly, Fig. 6b) in the initial 25 days were most favorable for 
1 encouraging the long-term trajectory of the LSSW from Ushant into the western

2 English Channel according to Salomon and Breton (1993). These southerly

3 component winds horizontally constrain the eastward flow of water, helping to

4 explain the extent of the low salinity intrusion captured by the ferry route in 2003 (Fig.

5 2b). Additional evidence of the wind driven influence on the transport of the LSSW

6 into the western English Channel is captured by the operational, data-assimilating

7 model Mercator (Bahurel et al., 2004) (Fig. 7). The simulated surface currents show

8 the transport into the western English Channel during the period of the low salinity

9 waters near Ushant in 2003 (Fig. 7).

10 In 2004, the arrival of the LSSW near Ushant coincided with time of weaker (cf.

11 2003) winds and surface currents after an initial 20 days of intrusion-favourable 12 southeasterly/southwesterly winds (weaker than in 2003 - model output from the

13 Mercator model does not show anything comparable to Fig. 7 during the time of the 14 low salinity waters near Ushant in 2004, not shown), the prevailing wind direction at 15 Ushant (and elsewhere along the French Atlantic coast, data not shown) was north16 northwesterly in the four-month period following the arrival of the LSSW near Ushant 17 (Fig. 6c). Such northerly component winds advect the LSSW westwards onto the 18 French Atlantic shelf, which helps to explain the location of low salinity water 19 offshore $\left(47^{\circ} \mathrm{N}-48^{\circ} \mathrm{N}\right)$, between spring and summer in 2004 (Fig. 2c). An additional 20 explanation for these low salinity $(<34.6$, section 3.1 .1$)$ offshore waters is that the 21 northwesterly winds (upwelling-favorable along the south Britanny coast) transport 22 the river plume waters (note the higher river outflow in 2004, particularly in May, 23 compared with the other years, Fig. 3a-c) offshore from the French coast thus creating 24 isolated less saline surface water. This is an offshore transport of at least 100 25 kilometres from the coast. Such features, termed "low salinity lenses", have been 
1 described before in the Bay of Biscay (Froidefond et al., 1996; Puillat et al., 2004).

2 This wind induced offshore transport is corroborated by model output from Mercator

3 which shows surface currents predominantly moving offshore between spring and

4 summer in 2004 (Fig. 8)

5 The appearance of a lower salinity lens (35-35.2) at $\sim 47^{\circ} \mathrm{N}$ in summer (days 150 -

6 190) 2003 (Fig. 2b) occurred once northwesterly winds prevailed (from day 143

7 onwards, Fig. 9). Also note that the appearance of this low salinity lens was preceded

8 by a small peak in river flows from both the Loire $\left(1120 \mathrm{~m}^{3} \mathrm{~s}^{-1}\right)$ and Gironde $\left(847 \mathrm{~m}^{3}\right.$

$9 \mathrm{~s}^{-1}$ ) in early May (day 125) (Fig. 3e). The higher salinity of this patch of offshore

10 water compared with 2004 corresponds to the lower river discharges in spring ( $>$ day

11 90) in 2003 (compare Figs. 4b and 4c). The higher river discharge in 2004 also

12 explains the high variability in salinity on the shelf compared to the other years

13 (section 3.1.1).

\subsection{The North Atlantic Oscillation (NAO)}

16 Many studies have linked variability in both hydrographical (Garcia-Soto et al., 2002) and ecological (e.g. Belgrano et al., 1999) phenomena in the northwest European shelf to the North Atlantic Oscillation (NAO), often through a measure known as the winter

19 (December-March) NAO index. Positive index values increase the likelihood of 1)

20 higher than average westerly winds, 2) storminess and 3) warmer and wetter years in 21 northern Europe, the converse of years with a negative NAO index. It might therefore 22 be expected that years with higher river discharges (2003 and 2004, Table 3) would 23 have a positive winter NAO index. However, 2004 has a negative index (Table 4). 24 Alternatively, years with stronger westerly winds might be expected to have a higher 25 positive NAO index. This expectation is supported in Table 4. The tentative 
1 conclusion is that in years with a positive NAO index there is an increased likelihood

2 that plume derived river waters from the French Atlantic coast make their way into

3 the western English Channel. However, there is need for a more long-term data set

4 before such a conclusion can be strengthened.

5 A plot of the winter NAO index alongside the salinity values in all years when there

6 was low salinity water near Ushant (Table 1, plus the FerryBox years) is shown in

$7 \quad$ Figure 9. It is tempting to suggest a possible link between these two phenomena given

8 the coincidence of peaks and troughs in some years (Fig. 10). However, statistical

9 analysis does not support this (overall $\mathrm{r}^{2}=0.1, \mathrm{p}=0.6$ ). In contrast, a link is suggested

10 by the fact that 16 (62\%) out of the 26 (including the data reported in this work)

11 occurrences of LSSW are associated with a positive winter NAO index (Fig. 10). This

12 may suggest that a positive NAO index (the more likely phase in a global warming

13 scenario, Shindell et al., 1999) increases the likelihood of LSSW near Ushant.

14 However, such a link seems counterintuitive given that the stronger westerly winds

15 arising out of a positive NAO index, do not encourage the northward spread of plumes

16 from French Atlantic rivers, according to Ekman theory.

18 5. Conclusions

19 Low salinity surface waters were observed close to Ushant between March and April 20 in 2002, 2003 and 2004. These waters are linked to the river plumes of the Loire and 21 Gironde which make their way northward along the French Atlantic coast during 22 winter and spring. Year to year variations in mean plume travel times along this coast 23 seem to be determined more by the interannual variability in prevailing winds rather 24 than river discharge magnitude. Mixed directional winds (southwesterly, southeasterly, 25 northeasterly) are associated with slower plume travel times than are consistently 
1 northeasterly winds during the period between peak river flows and the arrival of the

2 low salinity waters near Ushant, consistent with Ekman theory. Winter river outflows

3 were highest in 2004 and lowest in 2002, which explains the increasing freshness in

4 the low salinity signal near Ushant between 2002 and 2004.

5 The fate of the low salinity waters was determined by the state of the strong tides

6 around Ushant (spring or neap) and the weaker wind influenced long-term residual

7 flow into the western English Channel. The low salinity intrusion was freshest (and

8 extensive) in 2003 on account of 1) entering on a spring tide giving greater tidal

9 excursion into the western English Channel and 2) intrusion favourable winds

10 (southwesterly/southeasterly) acting on the longer term residual flow. This contrasts

11 with 2004 when the arrival of the low salinity water coincided with a neap tide

12 followed by intrusion-resistant, upwelling-favourable northerly component winds.

13 Consequently, most of the freshwater signal in this year travelled offshore onto the

14 French Atlantic shelf. In 2002, the lower volume of plume water relative to the other

15 years was more readily mixed by the strong spring tides producing a more saline

16 intrusion into the western English Channel. However, persistent westerly winds may

17 have pushed this intrusion northwards beyond the route of the ferry making it difficult

18 to assess the extent of the intrusion in 2002.

19 Observations of low salinity water near Ushant in all three years of data collection 20 on the Pride of Bilbao ferry, may result from the high frequency, year-round 21 monitoring capability of the FerryBox system, which contrasts with the lower 22 resolution data of all previous sampling studies in this region. It is therefore possible 23 that the low salinity feature near Ushant is more common than suggested by previous 24 data. The likelihood of low salinity waters reaching the southern entrance of the 25 western English Channel seems to be more associated with a positive NAO index (the 
1 more likely phase in a global warming scenario, Shindell et al., 1999), but a lack of

2 long-term data means that there is no strong evidence of a link with the NAO and low

3 salinity intrusions into the western English Channel.

5 Acknowledgements

6 This work has benefited greatly from the help and service of the following people:

$7 \quad$ Nick Crisp and John Campbell for technical skills in setting up and maintenance of

8 the FerryBox system, Mohammed Qurban, Sue Hartman, Stephanie Henson, Claire

9 Holten, Young Kim, Charlene Bargeron for help on the calibration crossings, Clive

10 Martin for helping to maintain the system and download the data on board the ship,

11 Maureen Edwards for designing and maintaining the FerryBox web pages

12 (http://www.soc.soton.ac.uk/ops/ferrybox_index.php), and the staff of P \& O

13 European Ferries Ltd. This work was supported by the European Commission under

14 the 5th RTD Framework Programme, Contract nº: EVK2-CT-2002-00144. Model

15 outputs of sea surface velocity were distributed by Mercator. C. Garcia-Soto

16 acknowledges financial support from the Spanish Ministry of Education

17 and Science (MEC) to the Project VEM 2004-08613. 


\section{References}

Armstrong, F.A.J., Butler, E.I., Boalch, G.T., 1974. Hydrographic and nutrient chemistry surveys in the western English Channel during 1965 and 1966. Journal of the Marine Biological Association of the United Kingdom 54, 895-914.

Bahurel, P, Dombrowsky, E.,Lellouche J.-M., and the Mercator project team (2004). Mercator Ocean Monitoring and Forecasting System, near-real time assimilation of satellite and in situ data in different operational ocean models. 36th International Liège Colloquium on Ocean Dynamics, Liège, Belgium, April 2004

Belgrano, A., Lindahl, O., Hernroth, B., 1999. North atlantic oscillation primary productivity and toxic phytoplankton in the Gullmar Fjord, Sweden (1985-1996). Proceedings of the Royal Society of London Series B-Biological Sciences 266 (1418), 425-430.

Bergeron, J-P.R., 1986. Approche systémique des potentialities de production secondaire pélagique: inférences de fluctuations interannuelles. Oceanologica Acta, 9 (3), 291-303.

Brylinski, J.M., Brunet, C., Bentley, D., Thoumelin, G., Hilde, D., 1996. Hydrography and phytoplankton biomass in the eastern english channel in spring 1992. Estuarine Coastal and Shelf Science 43 (4), 507-519.

Cooper, L.H.N., 1960. The water flow into the English Channel from the south-west. Journal of the Marine Biological Association of the United Kingdom 39, 173-208.

Cugier, P., Menesguen, A., Guillaud, J.F., 2005. Three-dimensional (3D) ecological modelling of the Bay of Seine (English Channel, France). Journal of Sea Research 54 (1), 104-124.

Dickson, H.N., 1891. Physical investigations. Report on physical investigations. Journal of the Marine Biological Association of the United Kingdom 2 (2-3),

Dietrich, G., 1962. Mean monthly temperature and salinity of the surface layer of the North Sea and adjacent waters from 1905 to 1954. Journal du Conseil Permanent International pour l' Exploration de la Mer (Service Hydrographique), p293

Froidefond, J.M., Castaing, P., Jouanneau, J.M., 1996. Distribution of suspended matter in a coastal up-welling area. Satellite data and in situ measurements. Journal of Marine Systems 8 (1-2), 91-105.

Garcia-Soto, C., Pingree, R.D., Valdes, L., 2002. Navidad development in the southern Bay of Biscay: Climate change and swoddy structure from remote sensing and in situ measurements. Journal of Geophysical Research-Oceans 107 (C8), art. no.3118.

ICES, 1956. Monthly means of surface temperature and salinity for areas of the North Sea and the Northeast North Atlantic. Service Hydrographique 
1 ICES, 1958. Monthly means of surface temperature and salinity for areas of the North

2 Sea and the Northeast North Atlantic. Service Hydrographique

ICES, 1975. Monthly means of surface temperature and salinity for areas of the North Sea and the Northeast North Atlantic. Service Hydrographique

Lacroix, G., Ruddick, K., Ozer, J., Lancelot, C., 2004. Modelling the impact of the Scheldt and Rhine/Meuse plumes on the salinity distribution in Belgian waters (southern North Sea). Journal of Sea Research 52 (3), 149-163.

Lazure, P., Jegou, A.M., 1998. 3D modelling of seasonal evolution of Loire and Gironde plumes on Biscay Bay continental shelf. Oceanologica Acta 21 (2), 165-177.

Lumby, J.R. 1935. Salinity and temperature of the English Channel. Estimation of mean values for the upper water layer over the 25-year period 1903 to 1927. Fishery investigations, Series II, Volume XIV (3). Ministry of Agriculture and Fisheries, Fisheries Laboratory, Lowestoft, p 109

Mariette, V., Lecann, B., 1985. Simulation of the formation of ushant thermal front. Continental Shelf Research 4 (6), 637-660.

Morin, P., Lecorre, P., Marty, Y., L’Helguen, S., 1991. Spring evolution of nutrients and phytoplankton on the Armorican shelf (north-west European shelf). Oceanologica Acta 14 (3), 263-279.

Pingree, R.D., Maddock, L., 1977. Tidal residual in the english channel. Journal of the Marine Biological Association of the United Kingdom 57, 339-354.

Pingree, R.D. 1980. Physical oceanography of the Celtic Sea and English Channel. In: Banner, F. T., Collins, M. B., Massie, K. S. (Eds), The north-west european shelf seas: The seabed and the sea in motion 2. Physical and chemical oceanography and physical resources. Elsevier, New York, pp 638.

Pingree, R.D., Mardell, G.T., Holligan, P.M., Griffiths, D.K., Smithers, J., 1982. Celtic sea and armorican current structure and the vertical distributions of temperature and chlorophyll. Continental Shelf Research 1 (1), 99-116.

Pingree, R.D., Le Cann, B., 1990. Structure, strength and seasonality of the slope currents in the bay of biscay region. Journal of the Marine Biological Association of the United Kingdom 70 (4), 857-885.

Poole, H.H., Atkins, W.R.G., 1929. Photo-electric measurements of submarine illumination throughout the year. Journal of the Marine Biological Association of the United Kingdom 16, 297-324.

Puillat, I., Lazure, P., Jegou, A.M., Lampert, L., Miller, P.I., 2004. Hydrographical variability on the French continental shelf in the Bay of Biscay, during the 1990s. Continental Shelf Research 24 (10), 1143-1163. 
1 Rennell, J., 1793. Observations on a current that often prevails to the westward of 2 Scilly; endangering the safety of ships that approach the British Channel. 3 Philosophical transactions of the Royal Society of London 83, 182-200.

4

Salomon, J.C., Breton, M., 1993. An atlas of long-term currents in the Channel. Oceanologica Acta 16 (5-6), 439-448.

Shindell, D.T., Miller, R.L., Schmidt, G.A., Pandolfo, L., 1999. Simulation of recent northern winter climate trends by greenhouse-gas forcing. Nature 399, 452-455.

Taylor, A.H., Reid, P.C., Marsh, T.J., Jonas, T.D., Stephens, J.A., 1981. Year-to-year changes in the salinity of the eastern English Channel, 1948-1973 - a budget. Journal of the Marine Biological Association of the United Kingdom 61 (2), 489-507.

UNESCO, 1983. Algorithms for computation of fundamental properties of seawater, 1983. UNESCO Technical Paper in Marine Science. No. 44, pp 53.

Waeles, M., Riso, R.D., Maguer, J.F., Le Corre, P., 2004. Distribution and chemical speciation of dissolved cadmium and copper in the Loire estuary and north Biscay continental shelf, France. Estuarine Coastal and Shelf Science 59 (1), 49-57. 


\section{Figure captions}

2

3 Fig. 1. Map of ferry route and associated study area. (Continuous line is the ferry 4 route. The boxed region is region 290 in Dietrich (1962) used in Table 1.

5

6 Fig. 2. Salinity data along the route of the Pride of Bilbao (five-minute averaged data is posted) for 2002, 2003 and 2004. Salinity values < 34 (found mostly in the harbours -minimum 25.09- and elsewhere - see section 3.1.1) have the same colour as salinity values in the range 34-34.2. This avoids complicating the plot with many more colours. (X-axis: day $1=1^{\text {st }}$ January)

\section{1}

Fig. 3. River outflows (cumulative graph) from the Loire and Gironde between January and July for (a) 2002 (b) 2003 and (c) 2004. Time series of salinity between January and July from the FerryBox near Ushant $\left(48.5^{\circ} \mathrm{N}, 5.1^{\circ} \mathrm{W}\right)$ for (d) 2002 , (e) 2003 and (f) 2004. River data from the French National Database for Hydrometry and Hydrology (HYDRO). (X-axis: day $1=1^{\text {st }}$ January)

\section{7}

Fig. 4. Progressive vector diagrams of wind data (station Chassiron, Fig. 1) for the period between maximum outflows from the Loire and the arrival of low salinity waters near Ushant for a) 2002, b) 2003, c) 2004. Numbers indicate days (day $1=1^{\text {st }}$ January). Data provided by UK Meteorological Office. 
1 Fig. 5. Approximate tidal cycles at Ushant (St. Helier, Jersey, $49.18^{\circ} \mathrm{N}, 2.12^{\circ} \mathrm{W}$, Fig.

2 1) derived by subtracting 2 hours 45 minutes from the time stamp (R. Pingree, pers.

3 comm.) at the time of the arrival of the LSSW (indicated by black vertical line, see

4 also Table 3) in a) 2002 ,b) 2003 and c) 2004. Data provided by the National Tidal

5 and Sea Level Facility (UK).

6

7 Fig. 6. Progressive vector diagrams of wind data (station Ushant, Fig. 1) for the period

8 following the arrival of low salinity waters near Ushant for a) 2002, b) 2003, c) 2004.

9 Successive solid circles represent 10 day intervals. Numbers indicate days (day $1=1^{\text {st }}$

10 January). Data provided by UK Meteorological Office.

11

12 Fig. 7. Map of sea surface velocity $\left(\mathrm{cm} \mathrm{s}^{-1}\right)$ in the Armorican Shelf and Western 13 English Channel on day 106 of 2003 produced by the operational model Mercator 14 (PSY2V1 version, Bahurel et al., 2004). No tidal currents are present, the assimilation 15 of altimetric satellite data (SLA) is cut-off with low bathymetry (e.g. Armorican Shelf 16 and W English Channel) and the model is forced by winds and heat fluxes from the 17 European Centre for Medium-range Weather Forecast (ECMWF). Maps have a 18 resolution of $1 / 5^{\circ}$. Length of arrows indicate relative strength of surface current. No 19 data are available from the Mercator model for the first FerryBox year (2002).

21 Fig. 8. Maps (weekly intervals) of sea surface velocity $\left(\mathrm{cm} \mathrm{s}^{-1}\right)$ in the Armorican Shelf 22 and Western English Channel in spring and summer of 2004 produced by the 23 operational model Mercator (PSY2V1 version, Bahurel et al., 2004). Length of arrows 24 indicate relative strength of surface current. 
1 Fig. 9. Progressive vector diagrams of wind data (station Chassiron, Fig. 1) for the

2 period prior and during offshore salinity is lower than surrounding waters in 2003.

3 Successive solid circles represent 10 day intervals. Numbers indicate days (day $1=1^{\text {st }}$

4 January). Data provided by UK Meteorological Office.

5

6 Fig. 10. Time series of winter (December-March) NAO index and salinity in years 7 when low salinity $(<35)$ waters appeared near Ushant $\left(48.5^{\circ} \mathrm{N}, 5.1^{\circ} \mathrm{W}\right)-$ refer to

8 Table 1. (Source of the NAO index : Jim Hurrell, North Atlantic Oscillation Indices

9 Information, http://www.cgd.ucar.edu/cas/jhurrell/nao.stat.winter.html) 


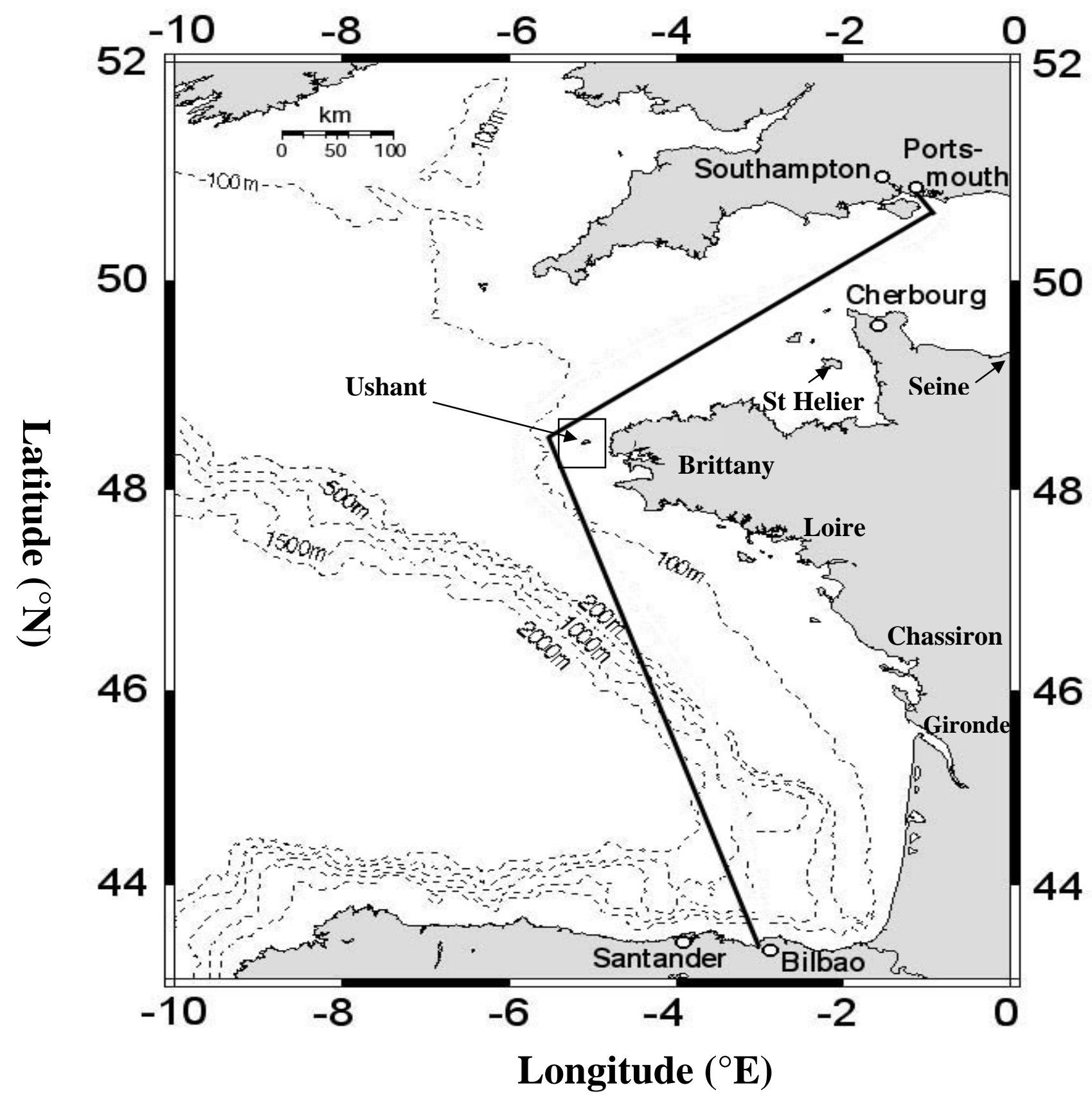



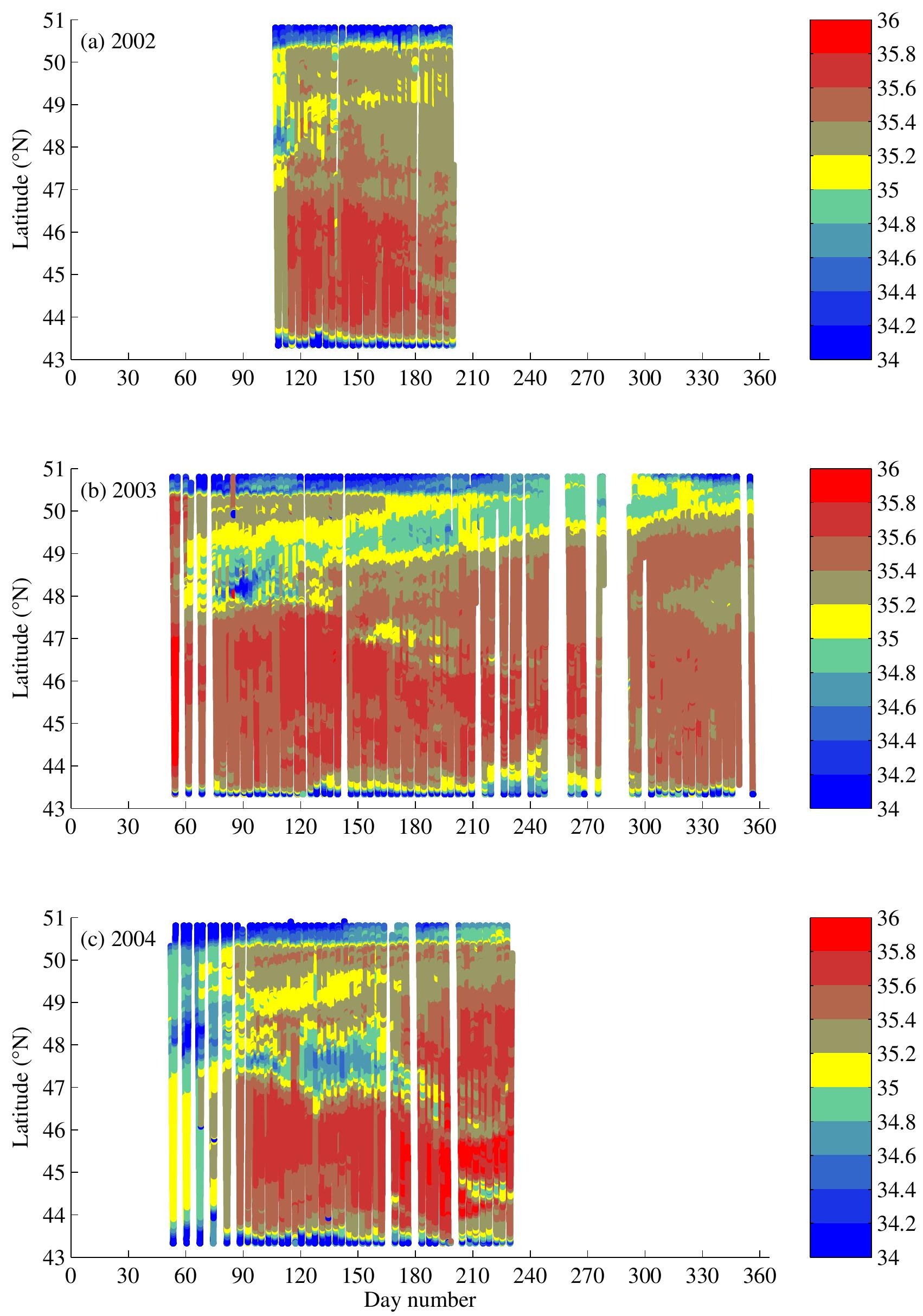

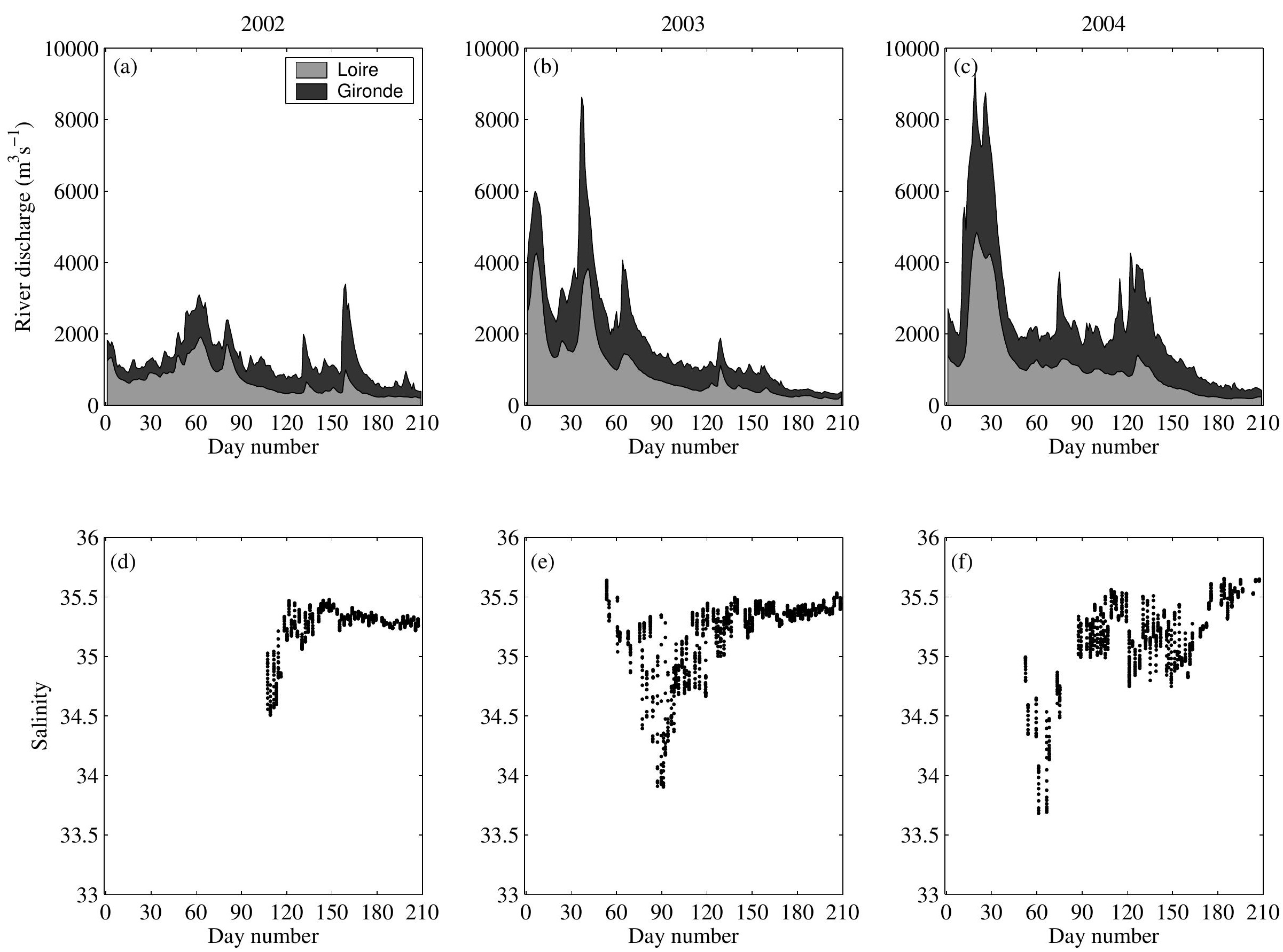

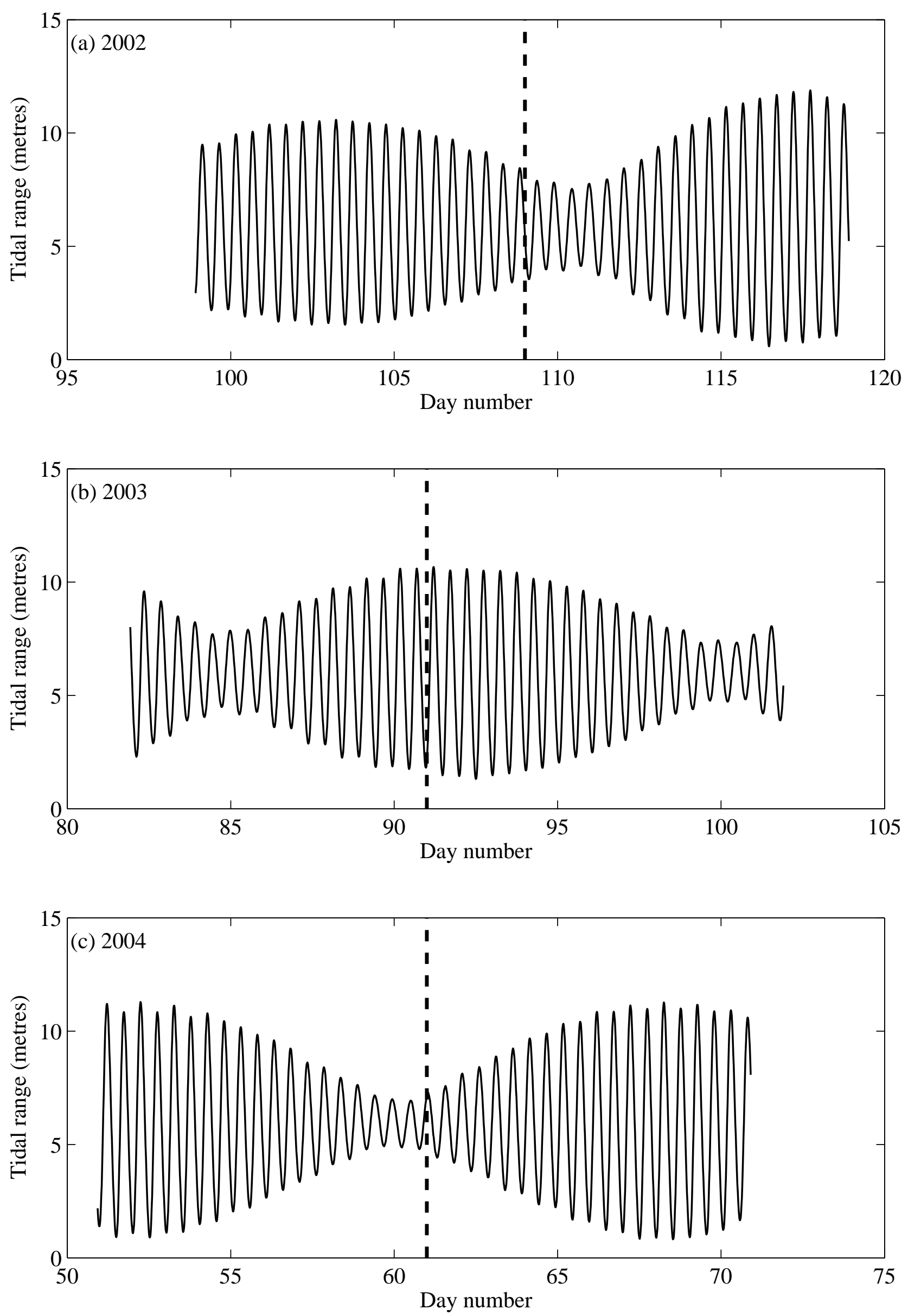
(a) 2002

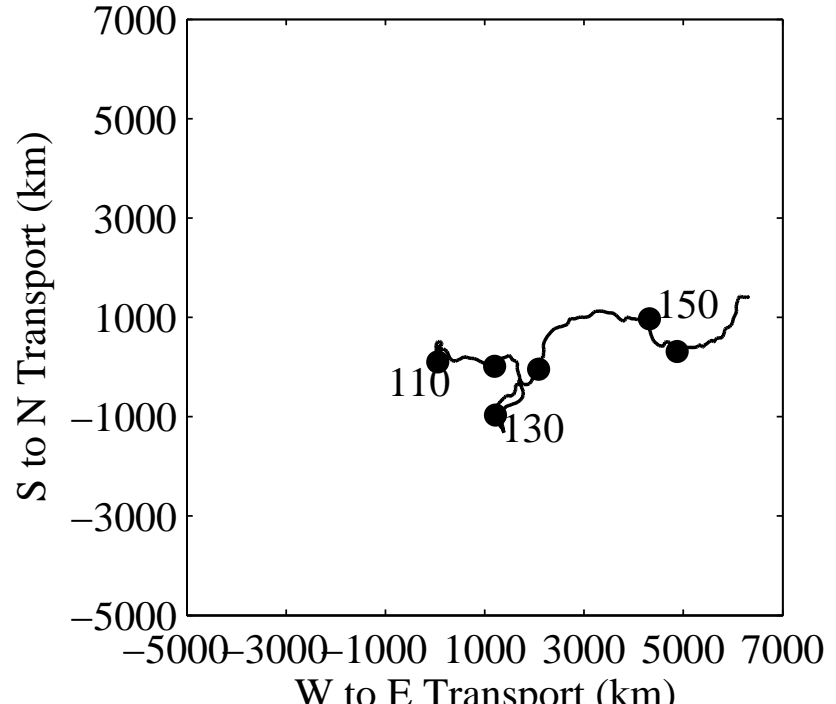

(b) 2003

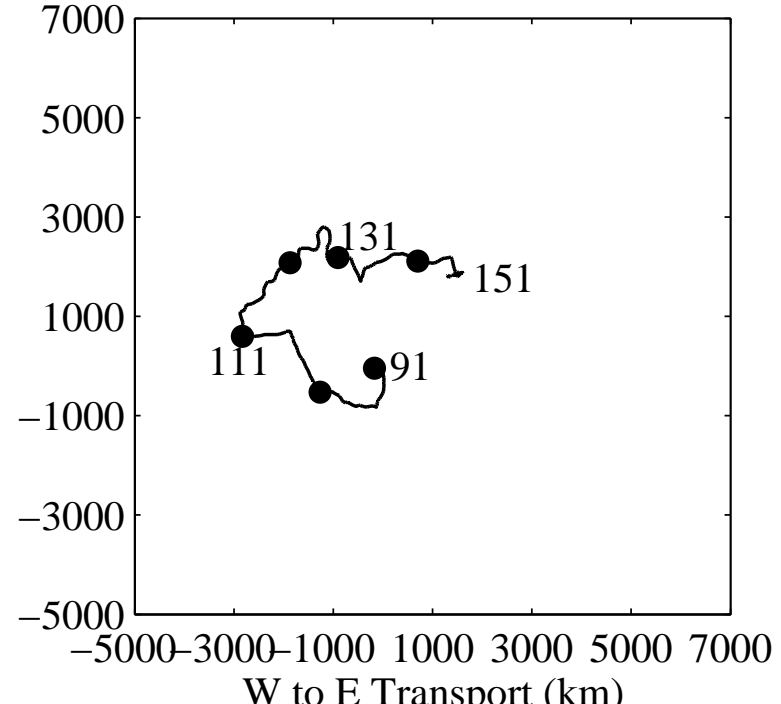

(c) 2004

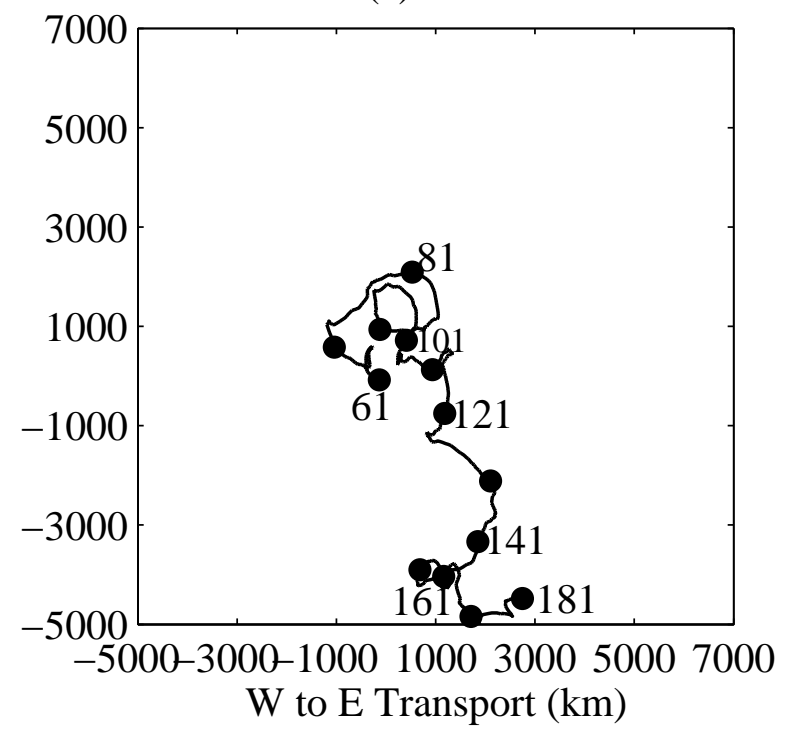


Fig 7

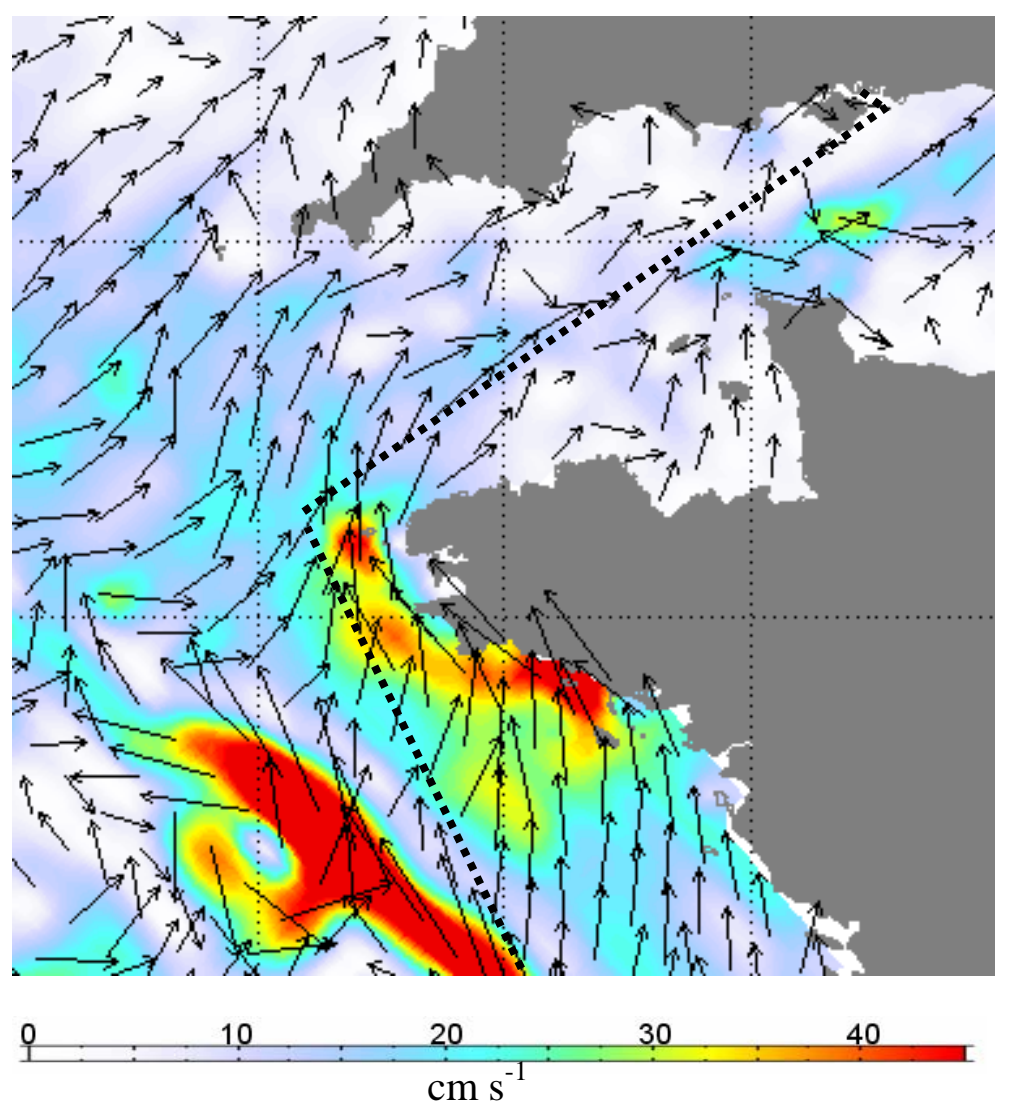


Fig. 8
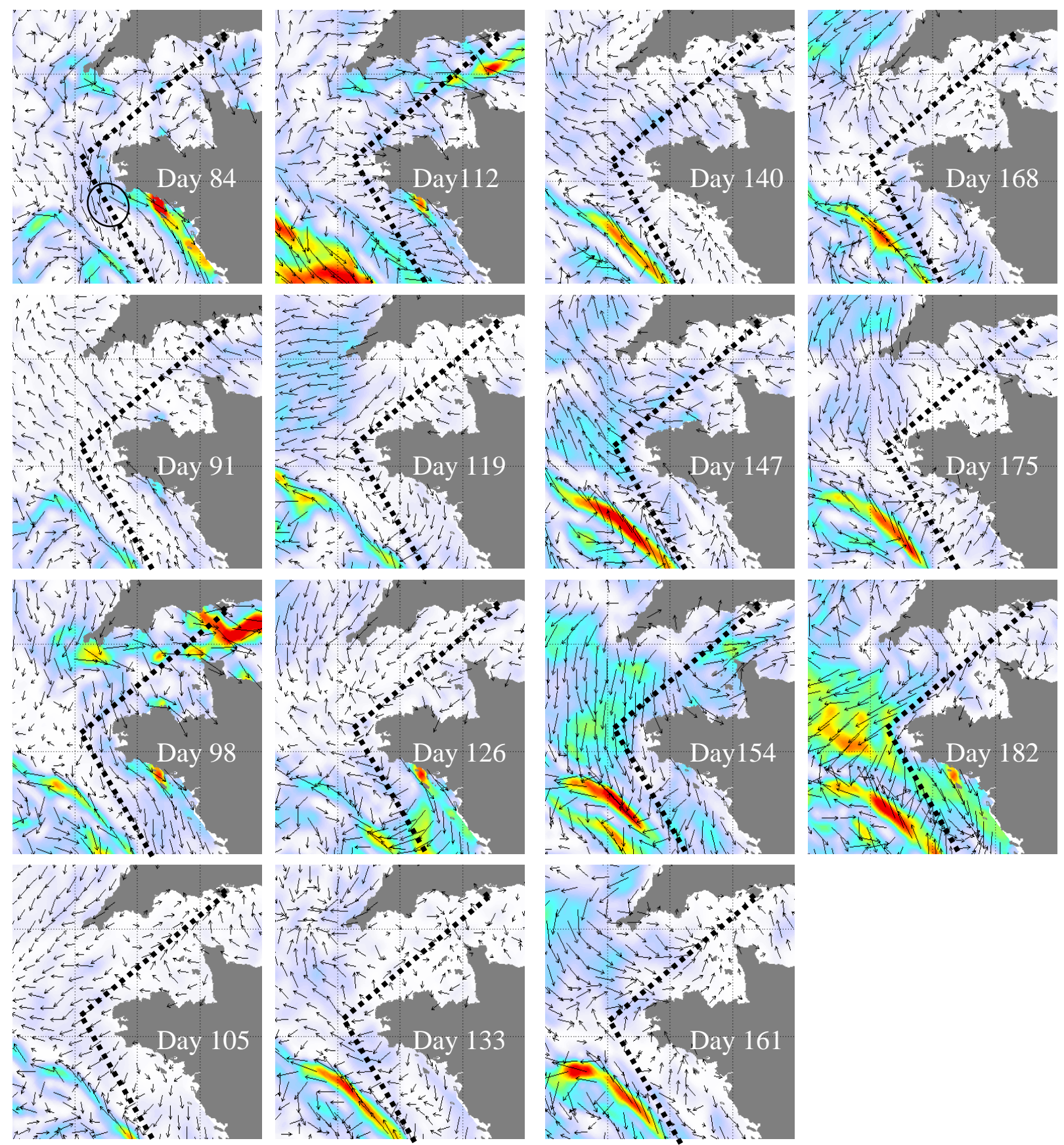

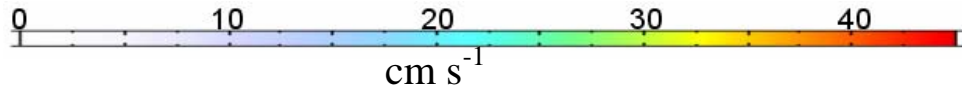




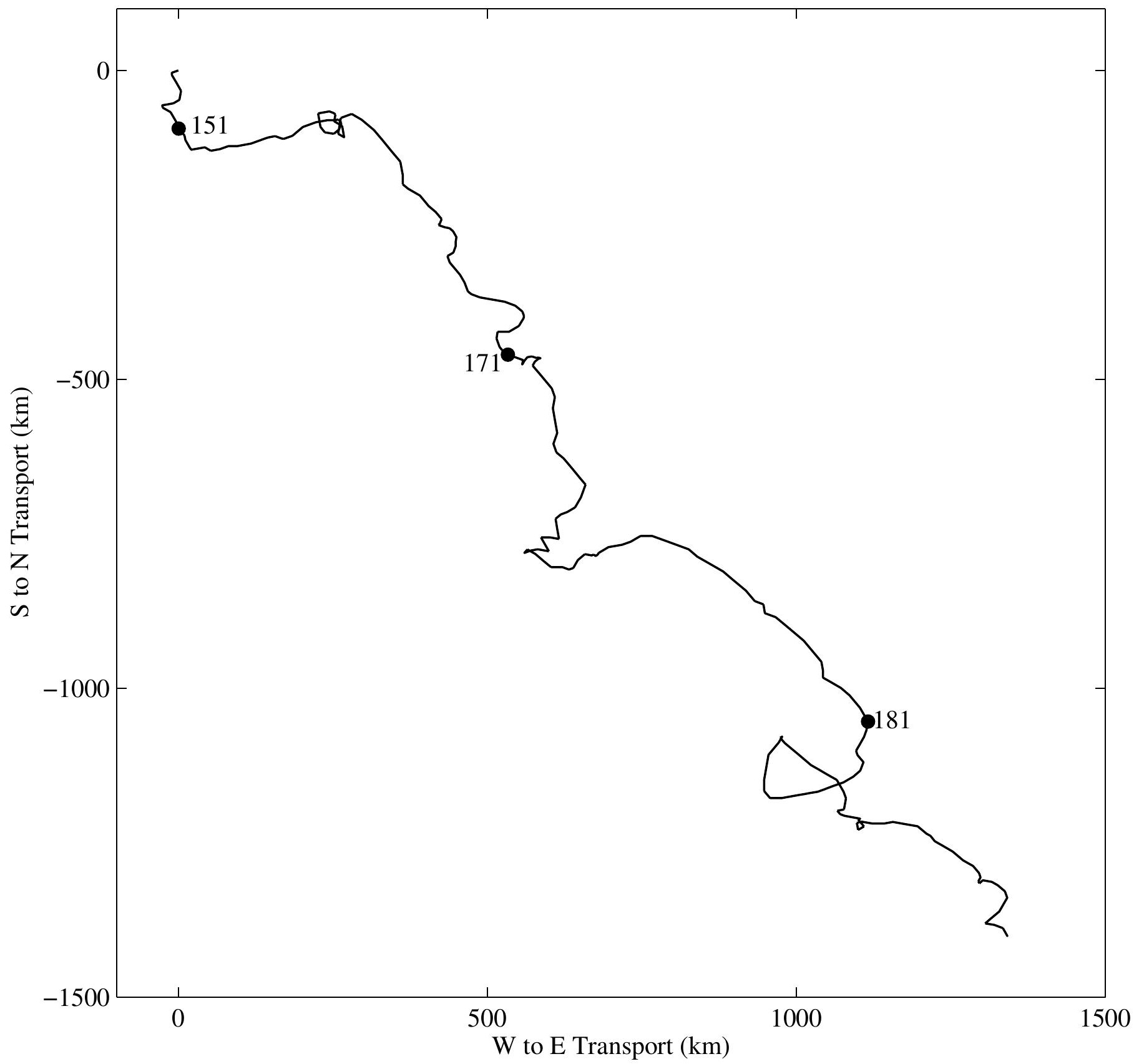




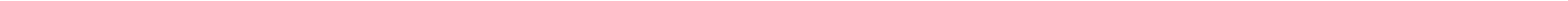


1 Table 1 . Incidences of low salinity surface water near Ushant $\left(48.5^{\circ} \mathrm{N}, 5.1^{\circ} \mathrm{W}\right)$ in late 2 winter-early spring since 1903. (Numbers in parenthesis refer to the number of 3 samples; data up to 1952 comes from region 290 in Dietrich, 1962, Fig. 1). Winter 4 (February-April) mean salinity for the period between 1905 and 1974 is 35.33 (this 5 value excludes salinities $<35$ ). This was calculated by adding the means calculated 6 for the period 1905-1954 (Dietrich, 1962) and 1955-1974 (ICES, 1956-1975)

\begin{tabular}{|lll|}
\hline Year & Salinity & Reference \\
\hline 1912 & $34.89(6)$ & Dietrich (1962) \\
1913 & $34.82(7)$ & Dietrich (1962) \\
1915 & $34.92(6)$ & Dietrich (1962) \\
1916 & $34.79(3)$ & Dietrich (1962) \\
1919 & $34.53(1)$ & Dietrich (1962) \\
1920 & $34.73(5)$ & Dietrich (1962) \\
1923 & $34.67(1)$ & Dietrich (1962) \\
1928 & $34.70(8)$ & Dietrich (1962) \\
1929 & $34.86(12)$ & Dietrich (1962) \\
1930 & $34.82(9)$ & Dietrich (1962) \\
1931 & $34.98(11)$ & Dietrich (1962) \\
1933 & $34.99(9)$ & Dietrich (1962) \\
1936 & $34.59(6)$ & Dietrich (1962) \\
1937 & $34.87(8)$ & Dietrich (1962) \\
1948 & $34.88(6)$ & Dietrich (1962) \\
1952 & $34.96(12)$ & Dietrich (1962) \\
1955 & $34.90(4)$ & ICES (1956) \\
1957 & $34.95(14)$ & ICES (1958) \\
1966 & 34.70 & Armstrong et al., (1974) \\
1974 & $34.75(1)$ & ICES (1975) \\
1979 & $<35$ & Bergeron (1986) \\
1980 & $<35$ & Bergeron (1986) \\
1982 & 34.95 & Morin (1991) \\
\hline
\end{tabular}


Table 2. Mean salinity values at different locations along the ferry route for 2002 (days 106-200), 2003 (days 77-200 ) and 2004 (days 60-200). Values in parenthesis are the standard deviations. Harbours are excluded.

\begin{tabular}{|c|c|c|c|c|c|}
\hline Year & $\begin{array}{c}\text { Western English } \\
\text { Channel } \\
\left(48-50.3^{\circ} \mathrm{N}\right)\end{array}$ & $\begin{array}{c}\text { Continental } \\
\text { shelf } \\
\left(47-48^{\circ} \mathrm{N}\right)\end{array}$ & $\begin{array}{c}\text { Shelf } \\
\text { break } \\
\left(46-47^{\circ} \mathrm{N}\right)\end{array}$ & $\begin{array}{c}\text { Bay of } \\
\text { Biscay } \\
\left(44-46^{\circ} \mathrm{N}\right)\end{array}$ & $\begin{array}{c}\text { Whole route } \\
\left(44-50.3^{\circ} \mathrm{N}\right)\end{array}$ \\
\hline 2002 & $35.25(0.12)$ & $35.36(0.11)$ & $\begin{array}{l}35.37 \\
(0.07)\end{array}$ & $\begin{array}{c}35.37 \\
(0.05)\end{array}$ & $35.29(0.12)$ \\
& $35.11(0.21)$ & $35.33(0.16)$ & 35.36 & 35.46 & $35.17(0.22)$ \\
& $35.20(0.23)$ & $34.95(0.26)$ & 35.23 & 35.20 & $35.16(0.25)$ \\
& & & $(0.18)$ & $(0.22)$ & \\
\hline
\end{tabular}

The mean values for salinity are significantly different among the years $(\mathrm{p}<0.0001)$ 
Table 3. River, wind (Chassiron, Fig. 1) and related statistics along the French Atlantic coast in the period between maximum outflow from the Loire and the arrival of the low salinity waters near Ushant in different years.

\begin{tabular}{|c|ccccccc|}
\hline Year & $\begin{array}{c}\text { MFlow }_{\mathrm{GL}} \\
\left(\mathrm{m}^{3} \mathrm{~s}^{-1)}\right.\end{array}$ & LSSW $_{\text {min }}$ & $\begin{array}{c}\text { LFlow }_{\mathrm{pt}} \\
(\text { day no. })\end{array}$ & $\begin{array}{c}\text { LSSW }_{\text {atu }} \\
(\text { day no. })\end{array}$ & $\begin{array}{c}\text { Plume }_{\mathrm{tt}} \\
(\text { days })\end{array}$ & $\begin{array}{c}\mathrm{U}_{\text {mean }} \\
\left(\mathrm{cm} \mathrm{s}^{-1}\right)\end{array}$ & $\begin{array}{c}\mathrm{W}_{\text {mean }} \\
\left(\mathrm{m} \mathrm{s}^{-1}\right)\end{array}$ \\
\cline { 2 - 7 } 2002 & 1579 & 34.51 & 62 & 109 & 47 & 6.4 & 5.5 \\
2003 & 3630 & 33.90 & 7 & 91 & 84 & 3.6 & 5.6 \\
& & & $41^{\mathrm{a}}$ & $91^{\mathrm{a}}$ & $50^{\mathrm{a}}$ & $6.0^{\mathrm{a}}$ & $4.8^{\mathrm{a}}$ \\
2004 & 4211 & 33.68 & 20 & 61 & 41 & 7.3 & 6.1 \\
\hline
\end{tabular}

MFlow $_{\mathrm{GL}}$ : mean combined flow of the Loire and Gironde between January and March

$\mathrm{LSSW}_{\min }$ : minimum recorded salinity in the low salinity water near Ushant

LFlow $_{\mathrm{pt}}$ : time of peak flow of the Loire

$\mathrm{LSSW}_{\text {atu}}$ : time of arrival of $\mathrm{LSSW}_{\min }$

Plume $_{\mathrm{tt}}$ : travel time of the plume between the Loire and Ushant

$\mathrm{U}_{\text {mean }}$ : mean current speed between the mouth of the Loire and Ushant. (distance $\sim 260 \mathrm{~km}$ )

$\mathrm{W}_{\text {mean }}$ : mean wind speed (station Chassiron, Fig. 1) during Plume $\mathrm{t}_{\mathrm{t}}$;

${ }^{\mathrm{a}}$ Statistics between second peak in the Loire discharge (day 41, Fig. 3b) and LSSW atu 
Table 4. Meteorological statistics for western approaches to the English Channel and the winter NAO index

\begin{tabular}{|c|cc|}
\hline Year & $\begin{array}{c}\text { Mean westerly wind } \\
\text { speed }^{\mathrm{b}}\left(\mathrm{m} \mathrm{s}^{-1}\right)\end{array}$ & $\begin{array}{c}\text { Winter NAO } \\
\text { index }^{\mathrm{c}}\end{array}$ \\
\cline { 2 - 3 } 2002 & 9.54 & 0.72 \\
2003 & 8.57 & 0.2 \\
2004 & 8.48 & -0.07 \\
\hline
\end{tabular}

${ }^{b}$ Ushant data calculated for winds from the direction range 265-275; ${ }^{\circ}$ DecemberMarch index (http://www.cgd.ucar.edu/cas/jhurrell/nao.stat.winte 